УДК 336.221.4:005.52(477)

Борейко Н.М., к.е.Н., старший науковий співробітник відділу розвитку податкового та митного аудиту, Науково-дослідний інститут фіскальної політики, Університет державної фіскальної служби України https://orcid.org/0000-0001-5808-4823

Параниця Н.В., к.е.н., доцент, доцент кафедри управлінського обліку, бізнес-аналітики та статистики Університет державної фіскальної служби України https://orcid.org/ 0000-0003-3682-4979

Boreiko N., Candidate of Sciences (Economics), Senior Researcher of the Department of Tax and Customs Audit Development, Research Institute of Fiscal Policy, University of the State Fiscal Service of Ukraine Paranytsia N., Candidate of Economic Sciences, Associate Professor, Associate Professor Department of Management Accounting, Business Analysis and Statistics, University of State Fiscal Service of Ukraine

\title{
СУЧАСНА ПРАКТИКА ОЦНЮВАННЯ ЕФЕКТИВНОСТІ ДІЯЛЬНОСТІ ПОДАТКОВИХ АУДИТОРІВ
}

\author{
Університет державної фіскальної служби Украӥни
}

Світові тенденції підвищення якості надання послуг державними установами у сфері публічного адміністрування спрямовані на оцінювання результатів їх діяльності. Систематичний моніторинг діяльності державних установ, у тому числі й органів податкової служби, дозволяє підвищити результативність їх діяльності, що в цілому позитивно відобразиться на економічному розвитку країни.

У статті поглиблено теоретичні засади щодо здійснення оцінювання ефективності діяльності податкових органів. Зокрема, зосереджено увагу на сучасній практиці оцінювання діяльності податкових аудиторів в Україні, адже саме від ефективності діяльності останніх залежить якість адміністрування податків та наповнення бюджету країни. Оскільки спеціальної методики, якою б регламентувались правові засади контролю повноти та якості проведення аудиту працівниками податкової служби поки не напрацьовано, це підтверджує актуальність проведення подальших досліджень 3 даної проблематики. Питання оцінювання ефективності діяльності податкових органів в Україні актуалізується також у зв'язку з реформуванням податкової служби.

Обгрунтовано, що одним із управлінських інструментів вирішення поставленого завдання $є$ використання системи ключових індикаторів оцінювання результативності (key performance indicators, КРІ), яка дозволяє охоплювати всі рівні діяльності установи. Система КРІ активно застосовується успішними компаніями у країнах з розвиненою економікою. Визначено, що у світовій практиці результативність діяльності податкових служб вимірюється на трьох основних рівнях: стратегічному, операційному та індивідуальному.

3'ясовано, що з метою запровадження системи оцінювання якості та повноти проведення аудиту необхідно враховувати такі критерії як навантаження, результативність, дієвість та економічність. Застосування такого підходу дозволяє зробити комплексне й деталізоване оцінювання повноти та якості податкового аудиту на різних рівнях.

Ключові слова: податкова служба, контроль, аудит, контролюючі органи, ефективність роботи, критерії оцінювання. 


\title{
MODERN PRACTICE OF EVALUATING THE EFFICIENCY OF THE ACTIVITIES OF TAX AUDITORS
}

\author{
University of State Fiscal Service of Ukraine
}

\begin{abstract}
Global trends in improving the quality of services provided by public institutions in the field of public administration are aimed at assessing the results of their activities. Systematic monitoring of the activities of state institutions, including tax authorities, can improve the effectiveness of their activities, which will positively affect the economic development of the country.

The article deepens the theoretical foundations for assessing the effectiveness of tax authorities. In particular, attention is focused on modern practice of assessing the activities of tax auditors in Ukraine, because the quality of tax administration and filling the country's budget depends on the effectiveness of the activities of the latter. Since a special methodology, no matter what the legal basis for controlling the completeness and quality of the audit by tax officials has been developed, has yet to be worked out, this confirms the relevance of further research on this issue. The issue of assessing the effectiveness of the tax authorities in Ukraine is also being updated in connection with the reform of the tax service.

It is proved that one of the management tools for solving the problem is the use of a system of key performance indicators (KPI), which allows you to cover all levels of the institution. The CWI system is actively used by successful companies in advanced economies. It is determined that in world practice the effectiveness of tax services is measured at three main levels: strategic, operational and individual.

It was established that in order to implement a system for assessing the quality and completeness of an audit, it is necessary to take into account such criteria as workloads, effectiveness, efficiency and profitability. The application of this approach allows you to make a comprehensive and detailed assessment of the completeness and quality of tax audits at various levels.
\end{abstract}

Keywords: Tax Service, control, audit, regulatory authorities, work efficiency, evaluation criteria

Постановка проблеми у загальному вигляді i ï зв'язок з важливими науковими та практичними завданнями. Питання ефективності діяльності податкових органів, у тому числі й здійснення ними податкового аудиту, є предметом дослідження як у вітчизняній, так і в зарубіжній практиці, адже розвиток будь-якої країни безпосередньо залежить від рівня наповнюваності бюджету, левову частину якого складають саме податкові надходження. У зв'язку з цим ефективність діяльності податкових органів часто ототожнюють саме 3 якістю діяльності податкових аудиторів.

Як зазначає у своїх наукових дослідженнях Міксел Дж., належна якість адміністрування податків напряму залежить від ефективності діяльності податкових аудиторів, а також від організації процедур адміністрування податків. Некомпетентність фахівців податкових органів може стати великою загрозою для податкової системи та держави в цілому [1]. Таким чином, досі актуальною залишається необхідність розробки стандартів оцінювання ефективності роботи податкових аудиторів.

Аналіз останніх досліджень, у яких започатковано вирішення проблеми. В умовах значної кількості порушень податкового законодавства, ухилення від оподаткування, питання оцінювання повноти та якості проведення аудиту фахівцями податкових органів постає надзвичайно гостро. У наукових колах дана проблематика досліджується багатьма вітчизняними вченими серед яких Бридун $€$. В., Вдовиченко А. М., Дугар Т. Є., Зубрицький А. І., Кирилюк I. В., Лещух І. В., Маланушенко С. Л., Мельник В. М., Мельник М. І., Проскура К. П., Серебрянський Д. М., Тимченко О. М. та інші. У своїх наукових працях вчені пропонують різні методи й інструментарій для реалізації контролю за повнотою та якістю податкового аудиту. Однак, у сучасних умовах дане питання досі $є$ актуальним та потребує додаткового вивчення, адже податкові органи нашої держави перебувають у стані реформування. 
Цілі статті. Метою статті є поглиблення теоретичних засад щодо аналізу сучасної практики оцінювання ефективності діяльності повноти та якості проведення податкового аудиту працівниками податкової служби.

Виклад основного матеріалу дослідження 3 повним обгрунтуванням отриманих наукових результатів. Як свідчить аналіз праць вітчизняних вчених, а також податкового законодавства, податковий аудит $\epsilon$ «процесуальними діями контролюючих органів, що вживаються ними 3 метою контролю правильності нарахування, повноти і своєчасності сплати податків і зборів у вигляді проведення перевірок» [2].

Спеціальної методики, яка б визначала правові засади контролю повноти та якості проведення аудиту працівниками податкової служби на даний час не напрацьовано. В основному розробки в цій сфері стосуються контролю діяльності митних органів. 3 метою надання оцінки повноти та якості проведеного податкового аудиту, керуються положеннями окремих нормативно-правових актів, методичними рекомендаціями та розпорядчими документами, а також листами-роз'ясненнями фіскальної служби (остання на даний час перебуває на етапі реформування). Щодо контролю проведення податкового аудиту можемо керуватися такими нормативно-правовими актами, як: Податковий кодекс України; постанова КМ України від 27.12.2010 № 1232 «Про затвердження Порядку проведення контролюючими органами зустрічних звірок» (зі змінами та доповненнями); постанова КМ України від 23.10.2013 № 805 «Про затвердження Порядку координації одночасного проведення планових перевірок (ревізій) контролюючими органами та органами державного фінансового контролю» (iз змінами та доповненнями); наказ МФ України від 20.08.2015 № 727 «Про затвердження Порядку оформлення результатів документальних перевірок дотримання законодавства України 3 питань державної митної справи, податкового, валютного та іншого законодавства платниками податків - юридичними особами та їх відокремленими підрозділами» (із змінами і доповненнями); наказ МФ України від 28.02.2017 № 299 «Про затвердження форми запиту контролюючого органу на проведення зустрічної звірки»; наказ ДФС України від 17.07.2015 № 511 «Про затвердження Методичних рекомендацій щодо організації та проведення органами державної фіскальної служби зустрічних звірок, обміну податковою інформацією при здійсненні податкового контролю» тощо.

Стратегічний план розвитку ДФС на 2015-2018 pр. свого часу було доповнено ціллю «Проведення регулярної оцінки ефективності роботи структурних підрозділів ДФС України та іiї територіальних органів, формування системи управління якістю їх роботи». Крім того було розроблено «Стратегічні ініціативи розвитку ДФС до 2020 року», в яких окреслено 9 напрямів стратегічного розвитку фіскальної служби. Серед них визначено також ціль впровадження системи стимулювання та оцінки ефективності персоналу, зокрема, розробка і впровадження основних показників ефективності (КРI) для оцінки структурних підрозділів та працівників [3].

На даний час ДФС України перебуває в режимі реорганізації (шляхом поділу на два окремі органи: Державну податкову та Державну митну служби), тож відповідно до розпорядження КМ України від 05.07.2019 № 542-р «Деякі питання реалізації концептуальних напрямів реформування системи органів, що реалізують державну податкову та митну політику», питання підбору висококваліфікованого персоналу, а також розробки заходів щодо оцінювання їх діяльності (у т. ч. й підрозділів, до повноважень яких входить здійснення податкового аудиту) є пріоритетними й для новоствореної ДПС України.

У світовій практиці, управлінським інструментом для вирішення такого завдання є система ключових індикаторів оцінювання результативності (key performance indicators, далі - KPI). KPI - це набір кількісних показників, які використовуються 
організацією з метою оцінки або порівняння результативності з точки зору досягнення стратегічних або оперативних цілей. У країнах з розвиненою економікою більшість компаній приватного та публічного секторів економіки функціонують на основі КРI [4]. Таким чином, доцільним $є$ запровадження системи КРІ й для оцінювання ефективності роботи податкового аудитора.

Як засвідчує світова практика, результативність діяльності податкових служб вимірюється на трьох основних рівнях [4]:

a) стратегічному - оцінюється результативність організації в цілому за допомогою ряду ключових показників, що, як правило, спрямовані на вимірювання фінансових результатів, рівня задоволення клієнтів, якості менеджменту та компетенції персоналу;

б) операційному - оцінюються безпосередні процеси та операції, направлені на досягнення цілей організації, а саме: якісне виконання покладених на неї функцій, що є необхідною умовою ефективного функціонування організації;

в) індивідуальному - спрямований на оцінювання результативності окремих працівників на основі визначених стандартів та цілей.

Концепція КРІ може охоплювати всі рівні діяльності установи, однак, у цьому дослідженні увага акцентована саме на оцінюванні повноти та якості проведення податкового аудиту фахівцями податкової служби, тобто, - індивідуальному рівні.

Деякі автори, розглядаючи критерії оцінювання ефективності діяльності податкових органів, виокремлюють щонайменше п'ять ключових індикаторів результативності, а саме: 1) загальний обсяг чистих податкових надходжень порівняно 3 прогнозними показниками; 2) загальні витрати порівняно із затвердженим бюджетом; 3) відношення витрат до надходжень; 4) частка добровільно сплачених податків та заповнених декларацій; 5) задоволення платників податків від діяльності податкових органів (за результатами проведення опитувань) [5, с. 32]. Застосування зазначених індикаторів дозволяє здійснити комплексне оцінювання результативності роботи податкового аудитора. Без сумніву, побудова системи контролю повноти та якості проведення податкового аудиту працівниками податкової служби повинна будуватися 3 урахуванням зазначених вище індикаторів.

Вчені виділяють 16 принципів, яким повинна відповідати ефективна система КРІ для досягнення максимального результату [5, с. 33-34], а саме: 1) узгодженість із стратегією та цілями організації; 2) фокусування на показниках стратегічної ваги; 3) репрезентативність; 4) реалістичність; 5) специфічність і зрозумілість індикаторів; 6) містить досяжні індикатори; 7) вимірюваність; 8) можливість слугувати базою для виведення загальних тенденцій; 9) погодженість 3 відповідальними за розрахунок особами; 10) публічність; 11) чітка визначеність підзвітності і відповідальності за формування показників; 12) періодичний перегляд індикаторів на предмет їх адекватності; 13) своєчасність; 14) зіставність (порівняння даних протягом різних часових проміжків, у межах цільових груп, тощо); 15) уникнення хибних стимулів; 16) об'єктивність. Застосування зазначених вище принципів дозволить не лише посилити ефективність діяльності контролюючих підрозділів, але й підвищити ефективність адміністрування податків.

Разом 3 тим у практиці побудови систем KPI виділяють так званий SMARTпринцип (від англ. smart - розумний), відповідно до якого система КРІ має бути: a) конкретною (specific) - націленою на конкретну сферу діяльності установи з метою їі удосконалення; б) вимірюваною (measurable) - вимірювати прогрес у діяльності установи; в) досяжною (achievable) - визначати, відповідальних за ії виконання; г) доречною (relevant) - передбачати, що поставлені завдання можуть бути реально досягнуті з урахуванням ресурсів, що є в установі; д) своєчасною (timely) - вказувати терміни досягнення результату [5, с. 35-36]. 
Аналіз наукових напрацювань 3 досліджуваної проблематики свідчить, що визначення критеріїв оцінювання якості та повноти проведення аудиту є складним науково-практичним завданням оскільки залежить від сукупності окремих чинників. Реалізацію цього завдання вбачається доцільним проводити комплексно, використовуючи наступні критерії: навантаження, результативності, дієвості та економічності [6, с. 176]. Такий підхід дозволяє всебічно й повно оцінити повноту та якість проведення податкового аудиту не лише окремим аудитором, чи підрозділом аудиту, але й у цілому по відомству.

Так, за критерієм навантаження можна здійснити розрахунок рівня макроекономічного, мезоекономічного (для порівняння показників податкового аудиту та його ефективності кількох територіальних податкових органів) та мікроекономічного навантаження контрольно-перевірочних заходів (аналіз ефективності діяльності конкретних суб'єктів контролю, тобто працівників податкового органу). Зокрема розрахунок рівня мікроекономічного навантаження контрольно-перевірочних заходів дозволяє здійснити оцінювання інтенсивності роботи інспектора, навантаження на одного податкового інспектора платниками податків, контрольного навантаження на платників податків податковими перевірками, рівня навантаження на платників податків донарахованими за результатами податкових перевірок платежами [6, с. 177].

Відповідно, критерій результативності дозволяє зробити: 1) аналіз результативних податкових перевірок у загальній кількості здійснених перевірок у процесі аудиту; 2) оцінку результативності податкових перевірок на одного податкового інспектора; 3) аналіз обсягів стягнень (відшкодувань) за результатами однієї податкової перевірки. Таким чином, здійснення аналізу повноти та якості податкового контролю за критерієм результативності дозволяє охарактеризувати конкретні результати діяльності працівників фіскальних органів при проведенні контрольно-перевірочних заходів. У свою чергу, критерій дієвості дозволяє визначити рівень жорсткості податкового аудиту, проаналізувати обсяги донарахувань за актами однієї перевірки, а також фактично сплачених податкових зобов'язань до бюджету з донарахованих за результатами податкових перевірок сум, розрахувати коефіцієнта якості податкового аудиту й зробити оцінювання «узгодженості» податкового контролю [6, с. 177]. В цілому за критерієм дієвості можна оцінити ефективність контрольно-перевірочної роботи податкових аудиторів, а також спроможність органів податкового контролю забезпечити своєчасну та в повному обсязі сплату платниками податків податкових зобов'язань до бюджету.

У свою чергу, за критерієм економічності можна здійснити: 1) аналіз витрат фіскальних органів на проведення одної перевірки; 2) оцінювання загальної економічної ефективності контрольно-перевірочної роботи податкових інспекторів; 3) аналіз вартості робочого часу, витраченого при проведенні перевірок податковими інспекторами [6, c. 177].

Застосування такого підходу дозволяє зробити комплексне й деталізоване оцінювання повноти та якості податкового аудиту на різних рівнях.

Висновки. Нині спеціалізованої методики діяльності податкових аудиторів для розкриття повноти та якості проведення аудиту податковими органами не напрацьовано. Як наслідок, одним з напрямів стратегічних ініціатив розвитку податкової служби є розробка і впровадження основних показників ефективності (КРІ) для оцінювання ефективності роботи структурних підрозділів та працівників. Для реалізації цього завдання мають бути визначені основні принципи побудови системи контролю повноти та якості проведення податкового аудиту, критерії оцінювання роботи податкового аудитора, а також наслідки оцінювання повноти та якості проведення такого аудиту.

Оцінювання повноти та якості проведення податкового аудиту фахівцями податкової служби (індивідуальний рівень оцінювання діяльності ДПС) пропонується здійснювати шляхом застосування таких критеріїв як навантаження, результативність, дієвість та 
економічність. Застосування такого підходу дозволить найбільш повно охопити всі аспекти контрольно-перевірочної діяльності та визначити: частку всіх податкових платежів (у т. ч. штрафних санкцій), донарахованих за результатами перевірок у загальному обсязі податкових надходжень; якість, результативність та ефективність перевірок за видами перевірок (у т. ч. у динаміці); навантаження на податкових інспекторів та ефективність їх діяльності; відповідність отриманих результатів критеріям віднесення суб'єктів господарювання до певного ступеню ризику; фіскальний ефект проведених перевірок тощо. Крім того такий підхід дозволяє встановити наслідки оцінювання повноти та якості проведення такого аудиту працівниками податкової служби і в цілому ДПС.

\section{Список бібліографічного опису}

1. John L. Mikesell. Administration and the Public Revenue System: A View of Tax Administration. 1974. № 34. Public Administration Review, 618 p.

2. Дугар Т. Є. Податковий аудит: проблеми європейського перетворення. Науковий вісник Міжнародного гуманітарного університету. 2017. URL: http://www.vestnik-econom.mgu.od.ua/journal/2017/25-2-2017/32.pdf (дата звернення: 10.06.2020).

3. Стратегічні ініціативи розвитку ДФС до 2020 року. URL: http://sfs.gov.ua/data/files/218923.pdf (дата звернення: 10.06.2020).

4. Хотенко О. Оцінка якості роботи ДФС за методикою КРІ: імітація чи вихід? ГО «Інститут податкових реформ». 15.04.2016. URL: http://ngoipr.org.ua/blog/otsinka-yakosti-roboti-dfs-za-metodikoyu-kpi-imitatsiya-chi-vihid/ (дата звернення: 10.06.2020).

5. Система ключових індикаторів результативності діяльності органів Міністерства доходів і зборів України: монографія / [Бридун С. В., Вдовиченко А. М., Зубрицький А. І., Кирилюк І. В., Маланушенко Є. Л., Серебрянський Д. М.]; за заг. ред. А. М. Вдовиченка. К.: Алерта, 2013. 336 с.

6. Мельник М. І., Лещух І. В. Податковий контроль в Україні: проблеми та пріоритети підвищення ефективності: монографія. Львів: ДУ «Інститут регіональних досліджень ім. М. І. Долішнього НАН України», 2015. 330 с.

\section{References}

1. Mikesell, John L. (1974), "Administration and the Public Revenue System: A View of Tax Administration", Public Administration Review, № 34, 618 p.

2. Dughar, T. Je. (2017), "Tax audit: problems of European transformation", Naukovyj visnyk Mizhnarodnogho ghumanitarnogho universytetu, available at: http://www.vestnik-econom.mgu.od.ua/journal/2017/25-2-2017/32.pdf (Accessed: 10 Jun. 2020).

3. State Fiscal Service of Ukraine, (2018), "Strategic initiatives for the development of the SFS until 2020", available at: http://sfs.gov.ua/data/files/218923.pdf (Accessed: 10 Jun. 2020).

4. Khotenko, O. (2016), "Assessment of the quality of SFS work according to the KPI method: imitation or out?" GhO "Instytut podatkovykh reform", available at: http://ngoipr.org.ua/blog/otsinka-yakosti-roboti-dfs-za-metodikoyu-kpiimitatsiya-chi-vihid/ (Accessed: 10 Jun. 2020).

5. Brydun, Je. V. Vdovychenko, A. M. Zubrycjkyj, A. I. Kyryljuk, I. V. Malanushenko, Je. L. and Serebrjansjkyj, D. M. (2013), Systema kljuchovykh indykatoriv rezuljtatyvnosti dijaljnosti orghaniv Ministerstva dokhodiv i zboriv Ukrajiny [System of key indicators the effectiveness of the bodies of the Ministry of Revenue and Duties of Ukraine], Kyiv: Alerta, Ukraine.

6. Meljnyk, M. I. and Leshhukh, I. V. (2015), Podatkovyj kontrolj v Ukrajini: problemy ta priorytety pidvyshhennja efektyvnosti [Tax control in Ukraine: problems and priorities for improving efficiency], DU "Instytut reghionaljnykh doslidzhenj im. M. I. Dolishnjogho NAN Ukrajiny", Ljviv, Ukraine.

Дата подання публікації 11.06.2020 р. 